\title{
REDESAIN INKLUSIF DAN PENINGKATAN AKSESIBILITAS LAYANAN UNTUK BERBAGAI PENGGUNA DI PERPUSTAKAAN UNIVERSITAS KRISTEN PETRA
}

\author{
Gunawan Tanuwidjaja ${ }^{1}$, Dian Wulandari ${ }^{2}$, Luciana Kristanto ${ }^{3}$ \\ 1. Prodi Arsitektur, Fakultas Teknik Sipil dan Perencanan, Universitas Kristen Petra, \\ Jl. Siwalankerto 121-131, Surabaya, dan Ph.D. Candidate of School of Design, Creative Industries \\ Faculty, Queensland University of Technology (Australia) \\ 2. Perpustakaan, Universitas Kristen Petra, \\ Jl. Siwalankerto 121-131, Surabaya \\ 3. Prodi Arsitektur, Fakultas Teknik Sipil dan Perencanan, Universitas Kristen Petra, \\ Jl. Siwalankerto 121-131, Surabaya \\ Email: gunte@petra.ac.id
}

\begin{abstract}
Abstrak
Dalam konteks Indonesia, UU No. 8 tahun 2016 sebenarnya telah mengakui hak Penyandang Disabilitas. Sayangnya, implementasi UNCRPD tampaknya tidak cukup efektif. Banyak fasilitas pendidikan tidak dapat diakses oleh para Penyandang Disabilitas atau PenDis. Lingkungan belajar memiliki dampak tidak langsung pada prestasi mahasiswa, menciptakan sikap yang positif, motivasi belajar yang lebih tinggi dan tak diragukan lagi performa yang lebih baik. Aspek aksesibilitas pada tempat belajar adalah hal yang krusial bagi fasilitas pendidikan seperti Perpustakaan Universitas di perguruan tinggi. Universitas Kristen Petra (UKP) terletak di jantung distrik Wonocolo, Surabaya, Jawa Timur-Indonesia. Dengan motto "zona belajar yang peduli", Library@Petra ingin menjadi pusat pembelajaran yang melayani akademisi dan praktisi. Library@Petra merupakan perpustakaan akademik terbesar dan terlengkap di Jawa Timur. Di sisi lain, banyak pengguna yang menemukan hambatan aksesibilitas di fasilitas milik Library@Petra yang dibangun pada tahun 1980-an. Isu aksesibilitas untuk seluruh pengguna dihasilkan dari Diskusi Kelompok Terfokus atau Focus Group Discussion (FGD), yang melibatkan PenDis, lansia, perempuan hamil berikut anak-anak sesuai Prinsip Berpusat pada Kebutuhan Pengguna (User-Centered Principle). Desain ulang Library@Petra ini diajukan berdasarkan prinsip-prinsip desain inklusif yang diajukan Tanuwidjaja (2015). Prinsip Penggunaan yang Setara tetapi Masuk Akal (Equitable Use but Reasonable Principle) akan dipenuhi melalui penyediaan pojok bantuan untuk pengguna berkebutuhan khusus, jalur yang mudah diakses dan ruang untuk berputar, serta area pertemuan dan toilet yang mudah diakses. Prinsip Kegunaan yang Sederhana dan Intuitif (Simple and Intuitive Use Principle) akan dipenuhi dengan penanda braille/visual dan pemandu arah untuk penyandang tuna netra. Prinsip Memerlukan Usaha Fisik yang Rendah (Low Physical Effort) diaplikasikan pada toilet yang mudah diakses dan bantuan untuk mengambil buku di areaarea tertentu yang sulit dijangkau, komputer untuk pengguna berkebutuhan khusus (pengguna tuna netra) disediakan untuk membaca, untuk mengakses e-book dan katalog. Pencegahan Kesalahan Penggunaan (Prohibition of Usage Error) dianjurkan (untuk diterapkan) dengan pemasangan pagar setinggi $150 \mathrm{~cm}$ di sekitar lorong lift serta lantai anti licin. Akan tetapi, rekomendasi - rekomendasi ini ternyata tidak dapat dipenuhi sekaligus karena keterbatasan anggaran Universitas dan penggunaan Library@Petra yang aktif sepanjang tahun. Untuk itu, maka diusulkan Pojok Bantuan untuk Pengguna Khusus termasuk Disabilitas sebagai langkah awal. Pojok ini dilengkapi dengan meja layanan pengguna khusus, sofa untuk menunggu dan 3 meja komputer untuk PenDis visual untuk membacakan situs $e$-book dan katalog. Rekomendasi dari kasus ini ialah perlunya PenDis lebih dilibatkan dalam desain inklusif.
\end{abstract}

Kata kunci: redesain, partisipatif, inklusif, aksesibilitas, disabilitas, perempuan hamil, lansia, anak-anak. 


\begin{abstract}
Title: Inclusive Design and Service Accessibility Improvement for Various Users in Petra Christian University Library
\end{abstract}

In the context of Indonesia, Act No. 8 of 2016 actually recognizes the rights of the disabled. Unfortunately, the UNCRPD implementation seems not quite effective. Many educational facilities are not accessible for the disabled or the People with Disabilities. The learning environment has an indirect impact on student achievement, creating a positive attitude, higher motivation for learning and no doubt better performance. The accessibility aspect of learning places is crucial for educational facilities such as university Library. Petra Christian University (UKP) is located in the heart of Wonocolo District, Surabaya, East Java-Indonesia. With the motto "Learning zone that cares ". Library@Petra wants to be a learning center that caters to academics, and practitioners.Library@Petra is the largest and most complete academic library in East Java. On the other hand, many users find accessibility barriers to Library@Petra-owned facilities built in the 1980 's. Accessibility issues for all users are generated from Focus Group discussion (FGD) discussions, involving people with disabilities, elderly, pregnant women following children in accordance with User - Centered Principle. The Library@Petra redesign was submitted based on the principles of inclusive design submitted by Tanuwidjaja (2015). An Equitable Use but Reasonable Principle will be met through providing a help corner for users with special needs, accessible pathways and space to spin, as well as accessible meeting and toilet areas. Simple and Intuitive Use Principle will be filled with braille/visual and directional guides for the blind and other. The principle of requiring Low Physical Effort applied to accessible toilets and assistance to retrieve books in specific areas that are hard to reach, computers for users with special needs (blind users) are provided for reading, to access e-books and catalogs. Prohibition of Usage Error is recommended with the installation of a fence as high as $150 \mathrm{~cm}$ around the elevator aisle and anti-slippery floor. These recommendations were found difficult to be addressed because of the limited university's budget and the use of active Library@Petra throughout the year. Therefore, it is proposed a Special Assistance Corner for special users including disability as a first step. This corner is equipped with a dedicated User Service desk, a waiting couch and three computer stations for visual disabilities to read ebook and catalogue sites. Recommendation of this case is the higher nvolvement of People with Disabilites in inclusive design.

Keywords: redesign, participative, inclusive, accessibility, disability, pregnant women, elderly, children.

\section{Pendahuluan}

Dalam konteks Indonesia, Undang Undang No. 8 tahun 2016 sebenarnya telah mengakui hak Penyandang Disabilitas atau PenDis sesuai rekomendasi UNCRPD (2007). Disabilitas adalah kondisi keterbatasan manusia yang terjadi pada nyaris semua orang, baik sementara ataupun permanen. Kondisi ini pada hakekatnya meningkatkan kesulitan fungsional diusia tua. Disabilitas menjadi fitur yang penting seiring dengan berubahnya demografi masyarakat dan semakin banyak orang yang hidup hingga masa tuanya (World Health Organisation \& World Bank (2011).

Sayangnya, pelaksanaan UNCRPD tampaknya tidak cukup efektif (Edwards, 2014) karena banyak fasilitas pendidikan tidak dapat diakses untuk PenDis. Hal ini juga didukung temuan Cameron \& Suarez (2017) juga berpendapat bahwa diskriminasi PenDis menyebabkan keterbatasan akses pendidikan, peluang ekonomi dan akses ke pelayanan publik, kemiskinan dan bahkan kesehatan yang buruk. 
Di sisi lain, lingkungan belajar memiliki dampak tidak langsung pada prestasi mahasiswa, menciptakan sikap yang positif, motivasi belajar yang lebih tinggi dan tak diragukan lagi performa yang lebih baik. Aspek aksesibilitas pada tempat belajar adalah hal yang krusial bagi fasilitas pendidikan seperti perpustakaan universitas (Robertson, 2012).

Universitas Kristen Petra (UKP) terletak di jantung distrik Wonocolo, Surabaya, Jawa Timur - Indonesia. Dengan motto "zona belajar yang peduli", Perpustakaan Universitas Kristen Petra (Library@Petra) ingin menjadi pusat pembelajaran yang melayani akademisi dan praktisi. Library@Petra merupakan Perpustakaan akademik terbesar dan terlengkap di Jawa Timur. Akan tetapi, di sisi lain, banyak pengguna yang menemukan hambatan aksesibilitas di fasilitas milik Library@Petra yang dibangun pada tahun 1980-an.

Paper ini dikembangkan kembali dari presentasi oleh Wulandari, dkk. (2017) dalam The $4^{\text {th }}$ International Conference on Creative Industry: Creative Experience.

Laporan Disabilitas oleh WHO dan Worldbank (2011) telah menggarisbawahi bahwasanya lebih dari satu milyar manusia di dunia hidup dengan disabilitas yang berbedabeda, yang mana hampir 200 juta diantaranya mengalami kesulitan fungsional yang berat. Hal ini telah diperkirakan, bahwa disabilitas akan menjadi perhatian yang lebih besar karena populasi yang semakin menua dan semakin tingginya resiko kondisi penyakit kronis seperti diabetes, penyakit kardiovaskular, kanker dan kelainan kesehatan mental (World
Health Organisation, \& World Bank (2011).

Menurut UU Republik Indonesia No. 8 Tahun 2016, pemerintah Indonesia menjamin setiap warga negara, termasuk PenDis bahwa mereka memiliki status hukum dan hak yang sama dengan warga negara Indonesia lainnya. Maka dari itu, proyek ini sangat penting untuk meningkatkan kemampuan para dosen sekaligus para mahasiswa dalam desain apapun untuk siapapun.

Undang - Undang ini juga mengamanatkan untuk menyediakan layanan disabilitas di fasilitas pendidikan, para PenDis (dosen, mahasiswa dan staf), lansia (bisa jadi dosen, staf dan orang tua), perempuan hamil (dosen dan staf), dan juga anakanak (anak dari dosen dan staf, serta pengunjung) akan membutuhkan akses yang setara dan aman untuk ke Library@Petra. Maka dari itulah, program Penyempurnaan Aksesibilitas Seluruh Pengguna di Perpustakaan Universitas Kristen Petra diajukan kepada Universitas Kristen Petra dan didukung oleh UBCHEA. Sehingga, kerangka Inclusive Design (Desain Inkusif dalam kasus ini dapat dikembangkan dengan mengadaptasikan konsep aslinya dari Inggris (The British Standards Institute/TBSI, 2005).

Sejumlah rekomendasi desain digali dari beberapa konsep, yaitu Universal Design (Desain Universal), Inclusive Design (Desain Inklusif) dan Participative Design (Desain Partisipatif). Desain Universal didefinisikan tidak hanya sebagai desain yang patuh pada kode dan standar aksesibilitas, tetapi juga menciptakan kenyamanan lingkungan desain untuk pengguna yang lebih luas 
(Nasar \& Evans-Cowley, 2007). Beberapa prinsip dari desain universal adalah kesetaraan dalam penggunaan, fleksibilitas penggunaan, penggunaan yang sederhana dan intuitif, informasi yang jelas, toleransi terhadap kesalahan, memerlukan upaya fisik yang rendah, serta menyediakan ukuran dan ruang untuk pendekatan dan penggunaan (Preiser \& Ostroff, 2001).

Yang kedua, Desain Inklusif didefinisikan sebagai "desain produk dan/atau layanan mainstream yang mudah diakses untuk, dan mudah digunakan oleh, sebanyak mungkin orang tanpa perlu ada adaptasi khusus maupun desain khusus". Desain Inklusif harus disertakan dalam proses desain yang paling awal (TBSI, 2005).

Levine (2003) mengusulkan perpustakaan sebagai fasilitas budaya harus menyediakan akses informasi dan pengetahuan untuk semua orang. Desain lokasi proyek ini harus menyediakan jalur jalan dan lahan parkir serta berbagai fasilitas lainnya yang aksesibel bagi PenDis.

Irvall \& Nielsen (2005) mengusulan checklist mengenai akses menuju perpustakaan untuk para PenDis. Maka seluruh bagian dari perpustakaan, pintu masuk, kamar mandi, tangga, elevator dan ruangan-ruangan khusus harus jadi lebih mudah diakses oleh para PenDis yang berbeda-beda. Seseorang yang berkursi roda harus bisa menjangkau seluruh departemen, seseorang dengan keterbatasan penglihatan harus bisa berjalan dengan tongkat atau anjing penuntun dan menemukan jalannya tanpa menabrak rintangan. Seorang tuli atau tuna rungu harus dapat berkomunikasi dengan staf perpustakaan. Seorang dengan keterbatasan intelektual harus bisa dengan mudah menemukan buku dan material lainnya. Seseorang yang memiliki disleksia atau gangguan baca lainnya harus dapat menemukan lokasi yang ditujunya. Maka dari itu, Desain Universal dari suatu perpustakaan sangatlah penting.

Robertson (2012) menyoroti perpustakaan sebagai pusat layanan yang dibutuhkan untuk mengakomodir kebutuhan semua murid dengan penunjang yang berbeda-beda untuk berbagai macam keberagaman. Staf perpustakaan harus secara proaktif memeriksa kebijakan dan standar layanan untuk mengurangi bahkan meniadakan batasan-batasan bagi PenDis. Hal ini bisa dilakukan dengan membuat format yang mudah diakses pada halaman situs web supaya pengguna yang kesulitan membaca karena disabilitas penglihatan maupun disleksia dapat menggunakan perangkat lunak pembaca layar dan layanan periode meminjam yang lebih panjang. Penyempurnaan juga bisa dilakukan dengan memperbaiki penanda arah dan lemari, tata letak rak, tata cara peminjaman dan lain - lain.

Akses fisik, penanda, kondisi akustik dan aksesibilitas harus dipertimbangkan saat perencanaan untuk mengantisipasi para penyandang keterbatasan gerak, keterbatasan pendengaran dan keterbatasan penglihatan. Akses fisik sangat penting karena akan menghubungkan antara area dalam ruangan dengan tempattempat yang berada di luar ruangan gedung, maka dari itu hal ini harus mengakomodir kebutuhan semua PenDis. Sangatlah penting bagi para staf untuk memahami peraturan aksesibilitas (Robertson, 2012).

Selain itu, terdapat studi tentang Desain Inklusif yang diperoleh dari 
Perpustakaan Auraria (Somerville \& Brown-Sica, 2011) yang diredesain kembali secara inklusif. Kasus ini menarik karena menggabungkan langkah perencanaan inklusif untuk penggunaan kembali spasial. Design Charrette (Lokakarya Desain) perpustakaan juga menggunakan Participatory Action Research dan memenuhi prinsip - prinsip desain inklusif untuk memenuhi kebutuhan pengguna yang dinamis. Sayangnya, dapat dikatakan bahwa proses ini tidak mudah diterapkan di negara - negara berkembang karena mengambil periode 18 bulan (termasuk Design Charrette/ Lokakarya Desain selama dua hari yang melibatkan stakeholder/ pemegang kepentingan dalam kampus). Oleh karena itu, proses Desain Inklusif harus disesuaikan untuk negara berkembang, seperti Indonesia.

\section{Metode Penelitian}

Riset ini dilakukan dengan metode kualitatif dan menggunakan Participatory Action Research seperti yang direkomendasikan oleh Somerville \& Brown-Sica (2011).

Secara umum beberapa langkah dilakukan untuk melaksanakan kegiatan ini adalah pertama, dilakukan tinjauan pustaka dan pemetaan spektrum seluruh pengguna (termasuk PenDis, lansia, perempuan hamil dan anak-anak) di Universitas Kristen Petra (UKP). Kedua, dilakukan dokumentasi aksesibilitas Library@Petra. Ketiga, dilakukan pelatihan sensitifitas untuk pustakawan, dosen dan mahasiswa yang terlibat dalam kegiatan program ini. Keempat, dibuat Desain Universal untuk Special Assistance Corner (Pojok Bantuan Pengguna). Kelima, dilakukan pembuatan maket untuk menunjang workshop Desain Inklusif.
Keenam, dilakukan workshop inklusif untuk desain perpustakaan yang melibatkan para PenDis, lansia, perempuan hamil dan anak-anak. Terakhir, dilakukan program bantuan pengguna di Library@Petra dan sosialisasi ulang layanan ini per tahun.

Tinjauan pustaka dilakukan dengan mengevaluasi standar kemudahan akses dan standar layanan perpustakaan yang aksesibel bagi PenDis. Studi kasus juga dikumpulkan untuk mendukung/menetapkan panduan desain perpustakaan yang mudah diakses.

Dalam proses pemetaan spektrum pengguna di UKP, beberapa pengguna dengan perlakuan khusus dapat ditemukan di kampus UKP. PenDis menjadi spektrum yang penting di kampus. Jumlah PenDis di kampus cukup banyak ditemukan. Sebagian besar karena kecelakaan olahraga, kecelakaan lalu lintas, atau menurunnya kesehatan, sehingga mereka menyandang disabilitas dalam waktu sementara. PenDis secara temporer juga ditemukan pada mahasiswa UKP, staf UKP dan juga para tamu yang berkunjung ke UKP.

Di sisi lain, sejumlah besar lansia khususnya dosen yang ditemukan bekerja di UKP membutuhkan akses menuju perpustakaan. Mereka berusia 60 tahun keatas dan mengajar secara paruh waktu. Mereka masih aktif tetapi kadang mereka kesulitan berjalan naik-turun tangga. Banyak dari mereka masih dipekerjakan karena penerapan prinsip LIGHT, penyediaan pekerjaan untuk lansia dan juga meneruskan pengalaman mengajar dan profesional mereka.

Banyak perempuan hamil dan perempuan yang membawa bayi yang 
dapat ditemukan dengan mudah di UKP yang juga membutuhkan akses yang setara. Mereka bekerja sebagai dosen dan staf di UKP. Mereka juga mengalami kesulitan saat berjalan naik dan turun tangga. Mereka juga kesulitan membawa banyak buku dari Library@Petra.

Anak-anak juga kadang ditemukan di UKP. Mereka adalah anak dari para dosen dan staf yang menunggu orang tua mereka sementara waktu, selama mereka liburan. Selain itu, beberapa aktivitas terkait anak usia sekolah dasar juga diadakan di Library@Petra, misalnya: Festival Film Sains (bekerjasama dengan German Institute), Surabaya Memory dan juga kunjungan anak-anak ke perpustakaan. Kebutuhan aksesibilitas anak-anak juga penting untuk difasilitasi.

Dokumentasi perpustakaan UKP dan simulasi sebagai PenDis diadakan pada Agustus 2016 sampai Januari 2017. Dokumentasi diadakan dengan melibatkan mahasiswa arsitektur dan interior. Dokumentasi umumnya dilaksanakan untuk menemukan permasalahan dan solusi konseptual yang memungkinkan. Sementara itu, simulasi sebagai PenDis diadakan untuk lebih memahami kebutuhan desain sekaligus menumbuhkan empati mahasiswa.

Selanjutnya, pada Januari 2017 telah dilakukan dokumentasi yang lebih menyeluruh oleh dosen dan dua mahasiswa dari departemen arsitektur untuk memilih bangunan dan perabotan yang sudah ada (untuk keperluan tertentu).

Perancangan ulang tata letak dan pencahayaan Desain Universal untuk Pojok Bantuan Pengguna garapan mahasiswa telah dilakukan pada bulan September - Desember 2016. Desainnya dikerjakan oleh KKP Desain Inklusi dan Sosiologi Desain, Sains Tata Cahaya pada tahap pertama.

Desain Universal yang dikerjakan oleh para dosen dikerjakan pada JanuariMaret 2017. Desainnya dikerjakan dalam lingkup pembahasan yang terintegrasi (Interior-Arsitektur-danManajemen Perpustakaan). Cakupan desainnya melibatkan desain ulang tata letak, desain perabotan Pojok Bantuan Pengguna, desain ulang pencahayaan. Sayangnya, karena keterbatasan waktu, hanya lantai 6 yang didesain ulang secara mendetail. Lantai 5, 7, dan 8 hanya sebatas dipertimbangkan/ didesain secara umum. Lift tambahan juga diajukan untuk menciptakan aksesibilitas ke semua lantai.

Lokakarya Desain Inklusif diadakan beberapa kali dengan melibatkan mahasiswa, PenDis, lansia, perempuan hamil, perempuan yang membawa bayi dan anak-anak. Lokakarya ini dilengkapi juga dengan menjadi pelatihan sensitifitas, penilaian kebutuhan awal dan pembahasan desain akhir.

Lokakarya Desain Inklusif akhir diadakan pada Maret 2017 melibatkan seluruh spektrum pengguna istimewa. Lokakarya ini menghasilkan konfirmasi dan masukan positif untuk perbaikan desainnya. Untuk dapat mengkomunikasikan desain bagi para PenDis visual, dibuatlah sebuah maket interior oleh para mahasiswa. Maket tersebut digunakan sebagai komunikasi desain dengan PenDis yang tuna netra.

Kampanye kreatif untuk Special Assistance Corner (Pojok Bantuan Pengguna Khusus termasuk Disabilitas) di Library@Petra dilakukan pada April-Mei 2017 dan 
diulangi pada Mei 2018 dengan melibatkan Pemerintah Kota, kepala sekolah dan guru dari Sekolah Luar Biasa, perwakilan PenDis serta pemerhati isu disabilitas lainnya. Pelibatan Unit Hubungan Masyarakat dan Media Massa (cetak, radio dan online) ternyata cukup meningkatkan jumlah PenDis yang datang dan memanfaatkan fasilitas ini.

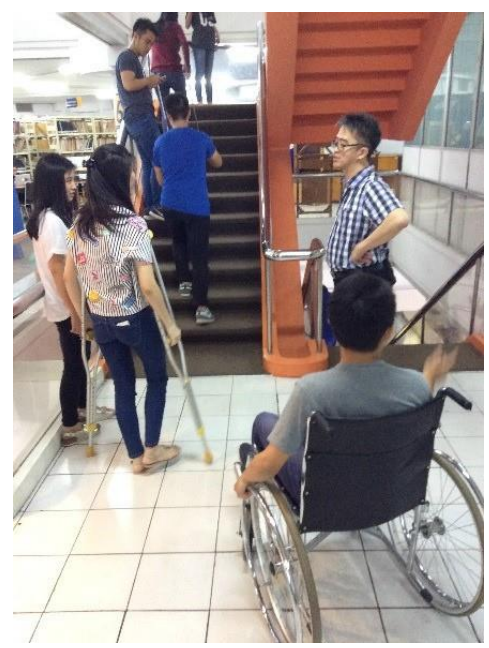

Gambar 1. Dokumentasi dan simulasi mahasiswa Service Learning Desain Inklusi sebagai disabilitas

Sumber: Dokumentasi Wulandari dkk., 2017

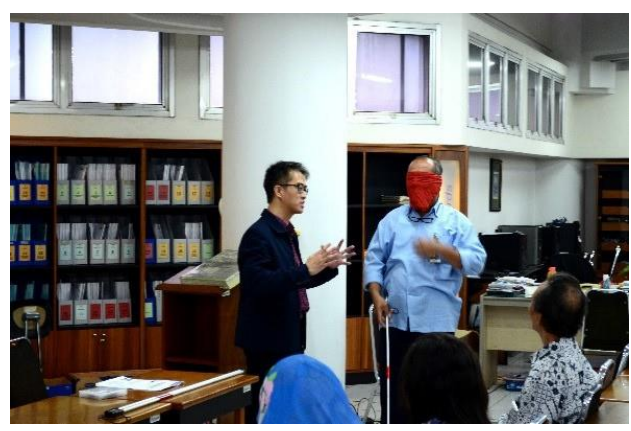

Gambar 2. Pelatihan sensitivitas Sumber: Dokumentasi Wulandari dkk., 2017

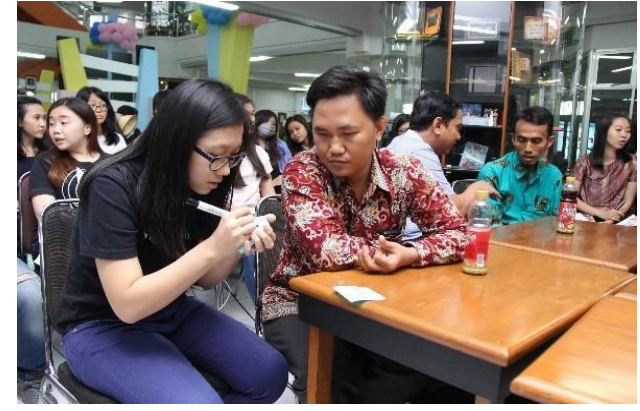

Gambar 3. PenDis visual memberikan masukan pada lokakarya Desain Inklusif Sumber: Dokumentasi Wulandari dkk., 2017

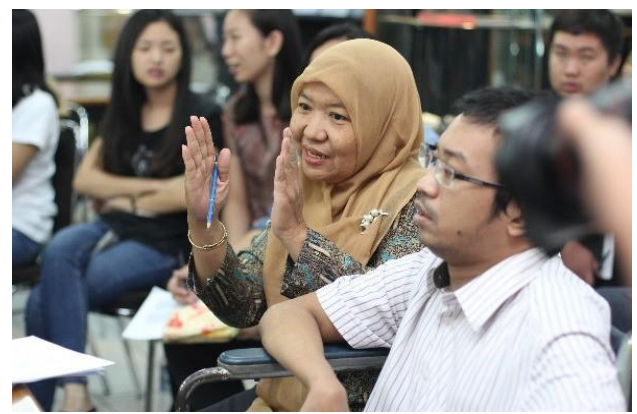

Gambar 4. PenDis daksa memberikan masukan pada lokakarya Desain Inklusif Sumber: Dokumentasi Wulandari dkk., 2017

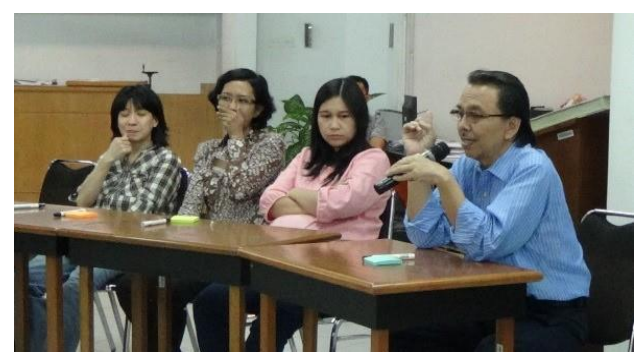

Gambar 5. Lansia dan perempuan hamil memberikan masukan pada lokakarya Desain Inklusif

Sumber: Dokumentasi Wulandari dkk., 2017

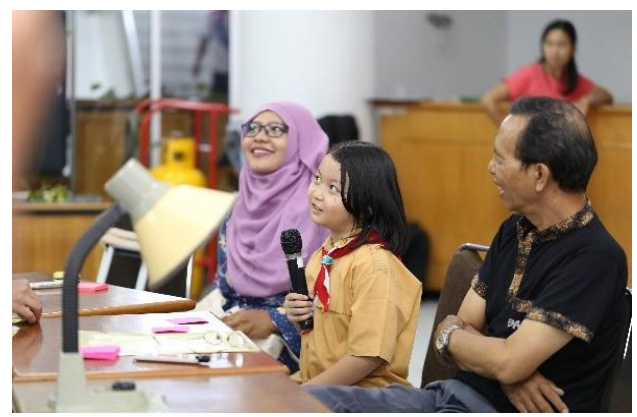

Gambar 6. Anak memberikan masukan pada lokakarya Desain Inklusif

Sumber: Dokumentasi Wulandari dkk., 2017 


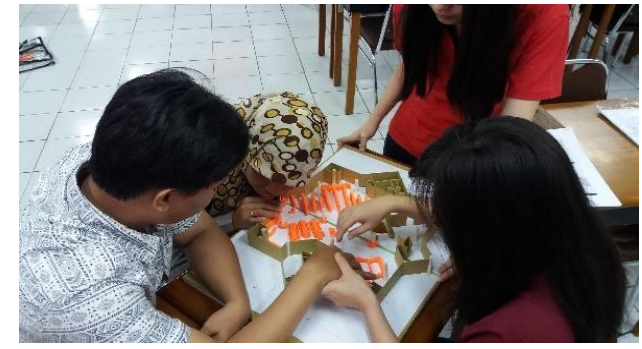

Gambar 7. Penggunaan maket dalam lokakarya Desain Inklusif

Sumber: Dokumentasi Wulandari dkk., 2017

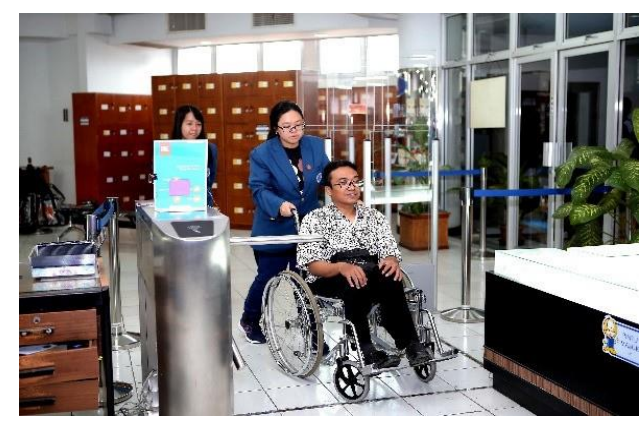

Gambar 8. Pelayanan PenDis dalam kampanye kreatif pada 2017

Sumber: Dokumentasi Wulandari dkk., 2017

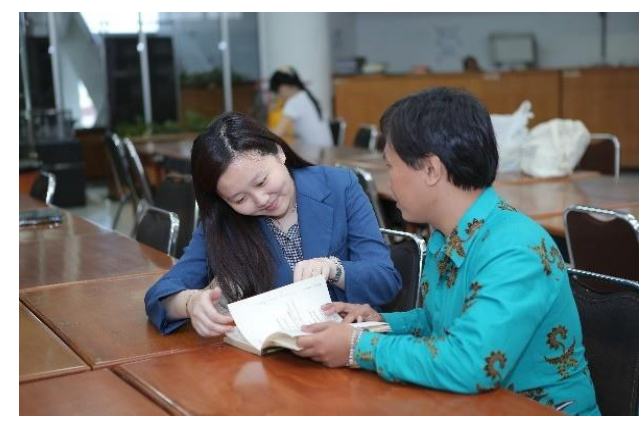

Gambar 9. Pelayanan PenDis dalam kampanye kreatif pada 2017

Sumber: Dokumentasi Wulandari dkk., 2017

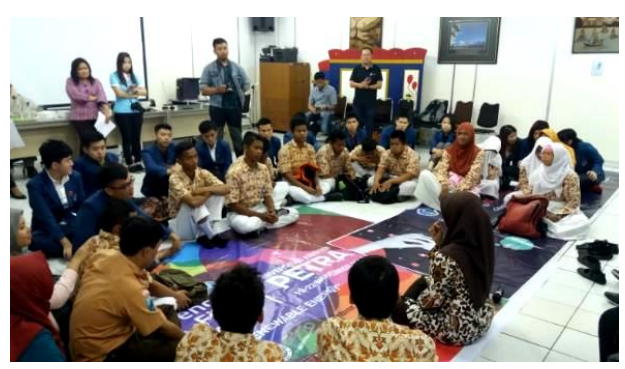

Gambar 10. Pelayanan PenDis dalam kampanye kreatif pada 2018

Sumber: Dokumentasi Tanuwidjaja dkk., 2020

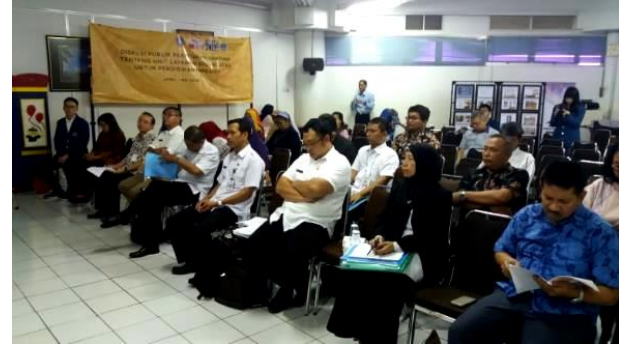

Gambar 11. Pelayanan PenDis dalam kampanye kreatif pada 2018

Sumber: Dokumentasi Tanuwidjaja dkk., 2020

\section{Hasil danPembahasan}

Desain ulang tata letak Library@Petra diajukan setelah proposal desain inklusif. Desainnya diproduksi sesuai prinsip berpusat pada pengguna karena mempertimbangkan kebutuhan PenDis, lansia, perempuan hamil, perempuan yang membawa bayi dan anak-anak. Desainnya mempertimbangkan aksesibilitas sosial dan aksesibilitas fisik.

Library@Petra berlokasi di lantai 5, 6, 7 dan 8 Gedung Radius Prawiro (di dalam bangunan). Perpustakaan dapat diakses dari lantai 6, tetapi lantai lain tidak bisa diakses melalui kebijakan manajemen terkait keamanan perpustakaan dan keterbatasan tenaga pustakawan. Maka dari itu untuk memenuhi penggunaan yang setara tapi masuk akal. Lift internal telah diusulkan juga untuk mewadahi kegiatan PenDis terutama PenDis berkursi roda, tetapi tidak memungkinkan karena struktur bangunan lama yang tidak dapat dibebani lagi.

Prinsip penggunaan setara tetapi masuk akal juga diusulkan dengan menyediakan jalur jalan/koridor yang mudah diakses (lebar bersih $100 \mathrm{~cm}$ ) dan ruang untuk berputar (dengan radius lebar bersih $150 \mathrm{~cm}$ ). Jalur jalan dan ruang berputar ini mengurangi area 
duduk dan beberapa tempat penyimpanan di dalam gedung. Di sisi lain, ada lebih banyak area pertemuan (terbuka atau tertutup) yang tersedia untuk memfasilitasi diskusi di perpustakaan. Toilet yang mudah diakses juga diajukan untuk menggantikan toilet pria di lantai 6 .

Prinsip ketiga yang diterapkan adalah penggunaan yang sederhana dan intuitif. Prinsip ini diterapkan dengan pengajuan sirkulasi sederhana. Sirkulasinya tidak dapat dirubah tetapi dapat disederhanakan dan dipertegas dengan penanda untuk seluruh pengguna dan pemandu arah untuk pengguna tuna netra. Pojok bantuan untuk pengguna istimewa ditempatkan di belakang area duduk di perpustakaan, tetapi hal ini dapat dipertegas dengan alat bantu lainnya (penanda dan pemandu arah).

Prinsip keempat adalah penggunaan usaha fisik yang rendah yang diterapkan dengan mengajukan toilet yang mudah diakses dan bantuan untuk mengambil buku di rak buku yang sulit diakses. Di sisi lain, buku-buku penting seperti buku referensi dapat di akses di lantai 6. Komputer tambahan untuk pengguna istimewa (terutama pengguna tuna netra) disediakan untuk membantu mereka membaca dan mengakses $e$-book dan situs web katalog.

Prinsip kelima pencegahan kesalahan penggunaan diajukan (untuk diterapkan) pada lorong lift dan toilet berakses mudah yang baru diajukan. Lorong sekeliling lubang void akan dilindungi dengan pagar kaca. Pagar tersebut disarankan memiliki tinggi $150 \mathrm{~cm}$. Toilet yang mudah diakses akan dilengkapi dengan susuran, lantai anti-licin, toilet duduk dan pintu geser. Karena tahapan perbaikan di
Library@Petra harus memperhatikan penganggaran dan batasan, maka diusulkan untuk mewujudkan Pojok Bantuan Pengguna Khusus termasuk PenDis yang berlokasi di lantai 6 . Desain pojok ini direncanakan oleh tim riset ini dari Prodi Desain Interior (Dr. Yusita dan Ibu Sherly) dan dirancang ulang oleh Tim Unit Perencana Fisik Kampus UKP dengan konsultasi dengan tim periset karena output yang berbeda kajian ini dipaparkan dalam paper terpisah.

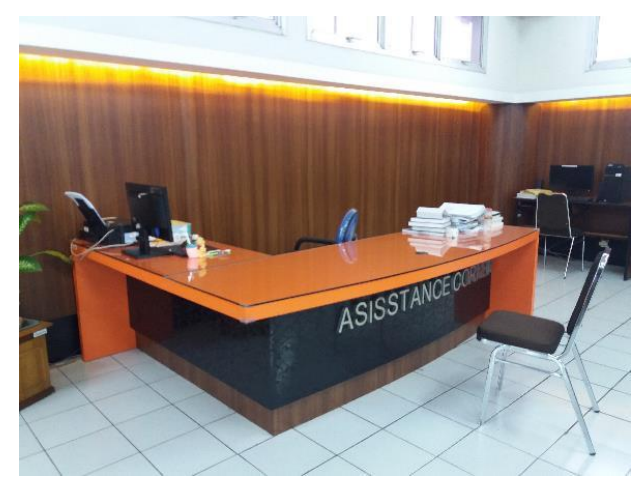

Gambar 12. Hasil konstruksi pojok bantuan pengguna khusus termasuk PenDis di Library@Petra

Sumber: Dokumentasi Tanuwidjaja dkk., 2020

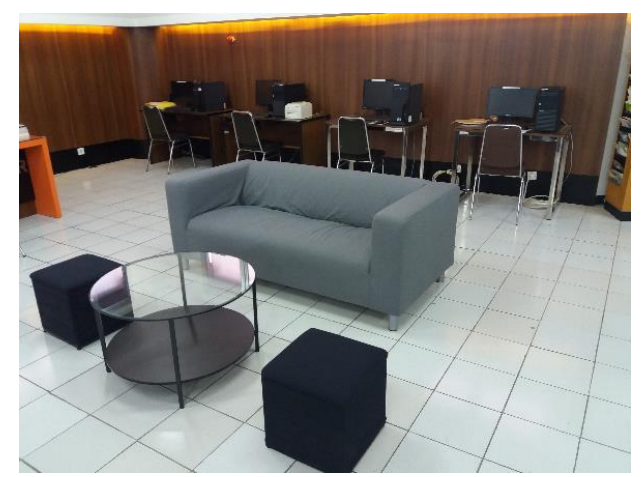

Gambar 13. Hasil konstruksi pojok bantuan pengguna khusus termasuk PenDis di Library@Petra, termasuk computer bicara untuk PenDis visual

Sumber: Dokumentasi Tanuwidjaja dkk., 2020 


\section{Kesimpulan}

Rekomendasi - rekomendasi ini ternyata ditemukan tidak dapat diwadahi sekaligus karena keterbatasan anggaran dan penggunaan Library@Petra yang aktif sepanjang tahun. Oleh karena itu, untuk langkah pertama diusulkan Pojok Bantuan untuk Pengguna Khusus termasuk Disabilitas sebagai langkah awal. Rekomendasi ini mendukung PenDis terlibat dalam desain inklusif untuk memastikan hak pendidikan mereka.

Proses yang dipaparkan dalam paper ini telah mempertimbangkan kondisi terpinggirkan PenDis di negara berkembang. Selain itu, juga diamati bahwa terdapatnya pengetahuan tentang Desain Inklusif atau Desain Universal di berbagai level manajemen ternyata membatasi juga realisasinya. Terakhir, kondisi sosial dan ekonomi negara berkembang juga membatasi realisasi perbaikan aksesibilitas di negara - negara berkembang.

Karena itu, diperlukan penyesuaian pada kerangka kerja desain inklusif yang ada seperti pemberdayaan berbasis budaya dari PenDis, seminar pendidikan standar Desain Inklusif untuk pengambil keputusan dan lokakarya partisipatif yang melibatkan PenDis di tingkat pemangku kepentingan utama.

\section{Ucapan Terima Kasih}

Pihak-pihak yang terlibat dalam program ini adalah:

- United Board for Christian Higher Education in Asia (https://unitedboard.org/)

- Ketua Tim dan Anggota Tim

o Dr. Yusita Kusumarini, S.Sn., M.Ds.

○ Sherly De Yong, S.Sn., M.T.
- Petinggi Universitas Kristen Petra:

- Rektor Universitas Kristen Petra, Prof. Ir. Rolly Intan, M.A.Sc., Dr.Eng. (tahun 2009-2017)

- Rektor Universitas Kristen Petra, Prof. Dr. Ir. Djwantoro Hardjito, M.Eng. (tahun 2018-2022)

o Kepala LPPM Universitas Kristen Petra, Dr. Juliana Anggono, S.T., M.Sc. (tahun 2014-2017)

- Kepala Biro Pengembangan Kerjasama dan Institusional, Meilinda, M.A. (tahun 20142017)

- Departemen terkait di Universitas Kristen Petra:

o Library@Petra

o Program Studi Desain Interior

- Program Studi Arsitektur

- Mahasiswa Program Service Learning di Prodi Arsitektur dan Prodi Desain Interior

- Narasumber:

- Eka Christian, S.Pd.

- Dr. Arina Hayati, S.T., M.T.

- Ahmad Fauzi, M.Hum.

- Lilik Ghoniyah Sofyan, M.Ed.

- Abdul Syakur, S.E.

- Tutus Setiawan, M.Pd.

Desy, S.Pd.

Atung Yunarto, M.Pd.

- Mohamad Ali Muhaidhori, M.Pd.

- Rully Damayanti, S.T., M.Art., Ph.D.

- Juliana Caesaria Tandung, S.E., M.Sc.

○ Olivia, S.E., M.A.

- Priskila Adiasih, S.E., M.Sc.

- Ir. I Gusti Nyoman Sulendra,

○ Ir. Bisatya Widadya Maer, M.T.

o Ir. Evelyn Pattikawa, M.T.

- Genevieve 
- Mitra Eksternal:

o Departemen Arsitektur, Institut Teknologi Sepuluh Nopember (ITS)

- YPAB (Yayasan Pendidikan Anak Buta) Surabaya

- YPAC (Yayasan Pembinaan Anak Cacat) Surabaya

- Mitra Pendukung: Lucent Pictures, HeavenArt-imagine, Maket Melekat, Nadia Maya Ardiani, Mercyruth Manyakory

\section{Daftar Pustaka/ Referensi}

Cameron, L., Suarez, D.C. (2017). Disability in Indonesia: What can we learn from the data? The Australia Indonesia Partnership for Economic Governance and Monash University, Department of Econometrics and Business Statistics and the Centre for Development Economics and Sustainability. Retrieved from https://www.monash.edu/_data/ assets/pdf_file/0003/1107138/Di sability-in-Indonesia.pdf

Edwards, N. (2014). Disability rights in Indonesia? Problems with ratification of the United Nations Convention on the Rights of Persons with Disabilities. Australian Journal of Asian Law 15 (1), Article 1. Retrieved from https://ssrn.com/abstract $=245981$ $8 \mathrm{a}$

Irvall, B., \& Nielsen, G. S. (2005). Access to libraries for persons with disabilities: Checklist. IFLA Professional Reports, No. 89. The Hague: International Federation of Library Associations and Institutions (IFLA).

Levine, D. (Eds.). (2003). Universal Design New York 2. The NYC guidebook to accessibility and universal design. New York: Center for Inclusive Design \& Environmental Access, University at Buffalo, The State University of New York.

Nasar, J.L., \& Evans-Cowley, J. (Eds.). (2007). Universal design and visitability: From accessibility to zoning. Columbus, Ohio: National Endowment for the Arts and the John Glenn School of Public Affairs.

Preiser, W., \& Ostroff, E. (Eds.). (2001). Universal design handbook. New York, USA: McGraw Hill.

Republic of Indonesia. (2016). Act no. 8 of year 2016 on person with disabilities. (Undang-Undang Republik Indonesia nomor 8 tahun 2016 tentang penyandang disabilitas). Jakarta: Lembaran Negara R.I.

Robertson, L. (2012). Access for library users with disabilities. London: The Society of College, National and University Libraries (SCONUL). Retrieved from

https://www.sconul.ac.uk/sites/d efault/files/documents/access_dis abilities_0.pdf

Somerville, M.M. \& Brown-Sica, M. (2011). Library space planning: A participatory action research approach. The Electronic Library 29(5), pp. 669-681.

The British Standards Institute. (2005). BS 7000-6: 2005 Design management systems - managing inclusive design - guide. London, UK: British Standards Institution.

United Nations. (2007). United Nations Convention on the Rights of Persons with Disabilities (UNCRPD). UN, New York: United Nations. 
World Health Organisation \& World Bank. (2011). World report on disability. Geneva, Washington DC: World Health Organization \& World Bank.

Wulandari, D., Tanuwidjaja, G., Kristanto, L., Yessica, Tondayana, A. Y. A., \& Hariyono, N. K. (2017). Creative accessibility improvement of all users in Petra Christian University Library. Proceedings of The $4^{\text {th }}$ International Conference on Creative Industry 2017: Creative Experience in Design, 103-114. Surabaya: ITS Press. 